\title{
MENSTRUATION DISCRIMINATION AND THE PROBLEM OF SHADOW PRECEDENTS
}

\section{DEBORAH A. WIDISS*}

The burgeoning menstrual justice movement highlights that women, girls, transgender men and boys, and non-binary persons may face discrimination or harassment due to their menstruation in workplaces, schools, prisons, and many other aspects of life. ${ }^{1}$ In recent years, a few courts have suggested such discrimination may violate Title VII, the federal law that prohibits sex discrimination in employment. ${ }^{2}$ Their analysis focuses on the Pregnancy Discrimination Act (PDA), an amendment to Title VII passed in response to a Supreme Court case holding that pregnancy discrimination was not sex discrimination. The PDA overrode the decision by explicitly defining sex as including "pregnancy, childbirth, or related medical conditions."3

The menstruation discrimination cases thus implicate more general questions of how statutory overrides should be interpreted, a subject I've explored extensively in prior work. ${ }^{4}$ My research suggests that this nascent litigation campaign may face two distinct challenges. The first is that courts will simply deny the claims, reasoning that menstruation is not directly addressed by the text of the PDA and therefore should not be

\footnotetext{
${ }^{*}$ Professor of Law and Ira C. Batman Fellow, Associate Dean for Research, Indiana University Maurer School of Law. Jordan Lee provided excellent research assistance on this essay. My thanks as well to the editors of the Columbia Journal of Gender and the Law for hosting the Are You There, Law? It's Me Menstruation symposium and for their conscientious work finalizing this essay for publication.

${ }^{1}$ See generally Margaret E. Johnson, Menstrual Justice, 53 U.C. DAvis L. REv. 1 (2019). Although a full explication of how to frame claims by transgender men and boys and nonbinary persons is outside the scope of this essay, I believe menstruation discrimination should be recognized as "sex" discrimination, regardless of the gender identity of the person menstruating. See also infra note 12.

${ }^{2}$ See infra Part III.

${ }^{3} 42$ U.S.C. $\S 2000 \mathrm{e}(\mathrm{k})$; see also infra Part II, discussing this history.

${ }^{4}$ See Brian J. Broughman \& Deborah A. Widiss, After the Override: An Empirical Analysis of Shadow Precedent, 46 J. Legal Studs. 51 (2017) [hereinafter Broughman \& Widiss, After the Override]; Deborah A. Widiss, Identifying Congressional Overrides Should Not Be This Hard, 92 TeX. L. Rev. SeE Also 145 (2014) [hereinafter Widiss, Identifying Overrides]; Deborah A. Widiss, Undermining Congressional Overrides: The Hydra Problem in Statutory Interpretation, 90 Tex. L. REv. 859 (2012) [hereinafter Widiss, Hydra]; Deborah A. Widiss, Shadow Precedents and the Separation of Powers: Statutory Interpretation of Congressional Overrides, 84 Notre Dame L. Rev. 511 (2009) [hereinafter Widiss, Shadow Precedents].
} 
recognized as sex discrimination. The second - which is more subtle, and also perhaps more likely - is that courts could find such discrimination to be actionable, but do so relying solely on the PDA's explicit reference to "medical conditions" related to pregnancy. While that would be helpful for addressing discrimination in workplaces, it could open the door to arguments that menstruation is outside the ambit of sex discrimination laws that were not amended in a manner analogous to how Title VII was amended.

To avoid these potential risks, theorists and advocates should seek to establish that menstruation discrimination is discrimination on the basis of "sex" itself, in that it is a condition linked to female reproductive organs and associated with stereotypes about women's inferiority. That reasoning, which suggests that the PDA is properly interpreted as signaling Congress's disapproval with the Supreme Court's unduly narrow understanding of what constitutes sex discrimination in the earlier pregnancy case, should apply not only to Title VII, but also to the interpretation of statutory and regulatory prohibitions on sex discrimination in non-employment contexts.

\section{Overrides and Shadow Precedents}

Under our tripartite system of government, Congress has ultimate authority over the meaning of statutory law. If Congress disagrees with a judicial interpretation of a statute, it can amend the statute, or enact a new statute, to supersede the judicial decision. This is known as enacting an "override." Although often described as the equivalent to a judicial overruling, overrides tend to be far less effective at ending reliance on the prior precedent. ${ }^{5}$ This is partially because courts may not even realize an override has been enacted, as Lexis and Westlaw are often slow to flag overrides. ${ }^{6}$

Even when courts are aware of the change in the law, however, overrides can pose difficult interpretive questions. This plays out along two "vectors." The first is whether and how enactment of the override changes interpretation of the preexisting language in the statute actually amended. Overrides are often written relatively narrowly to respond to a particular judicial decision. When faced with a new factual scenario that is similar to the issue addressed in a precedential case - but arguably not addressed by the language of the override - courts must determine whether the rationales expressed in the prior

\footnotetext{
${ }^{5}$ See generally Broughman \& Widiss, After the Override, supra note 4.

${ }^{6}$ See generally Widiss, Identifying Overrides, supra note 4.
} 
decision continue to control. My prior research shows that in these instances courts often continue to rely on overridden precedents, or what I've called "shadow precedents."

The second set of interpretive challenges is whether and how enactment of an override affects interpretation of language in other statutes that include similar language to the language interpreted in the overridden decision, but that were not themselves amended. In the employment discrimination context, this has led to extensive litigation over what causation standard applies to various statutes, because Congress responded to a Supreme Court decision on point by amending Title VII but did not amend other statutes modeled on Title VII. In several recent cases, the Supreme Court has held that Congress must have therefore "intended" a different causation standard to apply to these other statutes. ${ }^{8}$ While I have argued this inference is unwarranted, ${ }^{9}$ it is now firmly established in Supreme Court precedent.

In earlier writing, I've suggested that reliance on overridden precedents is frequently improper. I've proposed that courts should adopt a rebuttable presumption that preexisting language in a statute that is subject to an override, and similar language in other statutes, should be interpreted in line with the meaning Congress signals it prefers. ${ }^{10}$ However, as discussed in the parts that follow, advocates can also structure litigation to minimize the problem.

\section{Gilbert, the Pregnancy Discrimination Act, and Sex-Based Conditions}

Cases challenging discrimination based on menstruation build on fifty years of litigation and legislation addressing pregnancy discrimination. ${ }^{11}$ Title VII of the Civil Rights Act of 1964 prohibits sex discrimination in employment. Prior to its enactment, it was common for employers to fire employees when they became pregnant, and to offer less robust support for pregnancy than for other health conditions. In the 1970s, women used the then-new law to challenge these practices. Although the federal agency charged

\footnotetext{
${ }^{7}$ See generally Widiss, Shadow Precedents, supra note 4.

${ }^{8}$ See, e.g., Comcast Corp. v. Nat'l Assoc. of African-Am. Owned Media, 140 S. Ct. 1009, 1017-18 (2020); Gross v. F.B.L. Fin. Servs., 557 U.S. 167, 174-75 (2009).

${ }^{9}$ See generally Widiss, Hydra Problem, supra note 4.

${ }^{10}$ See id. at 933-38; Widiss, Shadow Precedents, supra note 4, at 566.

${ }^{11}$ I discuss this history more fully in Deborah A. Widiss, Gilbert Redux: The Interaction of the Pregnancy Discrimination Act and the Amended Americans with Disabilities Act, 46 U.C. DAVIS L. REV. 961 (2013).
} 
with interpreting Title VII and all circuit courts to consider the issue held that pregnancy discrimination was sex discrimination, ${ }^{12}$ the Supreme Court ultimately disagreed. In a 1976 decision, General Electric Co. v. Gilbert, a divided Court held that it was permissible to exclude pregnancy from an otherwise comprehensive disability plan, on the ground that the plan did not exclude anyone from eligibility because of sex per se. ${ }^{13}$ Three justices dissented, arguing that discrimination on the basis of a condition that is "unique to" one sex is properly recognized as sex discrimination, ${ }^{14}$ and that the capacity to become pregnant is a key distinction between men and women. ${ }^{15}$ The dissenting justices also noted that the exclusion reflected stereotypical assumptions that pregnant women would, and should, leave the workplace. ${ }^{16}$

The rule announced in Gilbert was short lived, at least as applied to pregnancy itself. Just one year later, in Nashville Gas Co. v. Satty, the Court considered a challenge to a policy that denied accumulated seniority to women after maternity leave. Rather than follow Gilbert, the Court held that the policy was illegal because it "imposed on women a substantial burden that men need not suffer" without a sufficient business justification. ${ }^{17}$ The year after that, Congress overrode Gilbert directly by enacting the Pregnancy Discrimination Act (PDA). The PDA added a new definition to Title VII, indicating that the terms "'because of sex' or 'on the basis of sex,' include, but are not limited to, because of or on the basis of pregnancy, childbirth, or related medical conditions." 18

${ }^{12}$ See Gen. Elec. Co. v. Gilbert, 429 U.S. 125, 147 (1976), superseded by statute, Pub. L. No. 95-555, 92 Stat. 2076 (1978), (Brennan, J., dissenting) (collecting circuit court cases holding pregnancy discrimination to be actionable sex discrimination).

${ }^{13}$ See id. at $138-39$.

${ }^{14}$ See id. at $159-60$ (Brennan, J., concurring and dissenting). The assumption that pregnancy is "unique to" women fails to recognize that transmen and non-binary persons may also become pregnant. Likewise, anyone with female reproductive organs may menstruate. However, both pregnancy and menstruation can be described as "unique to" individuals with female reproductive organs or linked to biological sex, suggesting this reasoning could support a claim of sex discrimination even in cases brought by transgender or non-binary persons.

${ }^{15}$ See id. at 162-63 (Stevens, J., dissenting).

${ }^{16}$ See id. at 159-60 (Brennan, J., concurring and dissenting).

${ }^{17} 434$ U.S. 136, 142 (1977).

1842 U.S.C. $\S 2000 \mathrm{e}(\mathrm{k})$. The definition also provides that women affected by "pregnancy, childbirth or medical related medical conditions shall be treated the same for all employment-related purposes" as others with a similar "ability or inability to work." $I d$. 
In its first major decision interpreting the PDA, the Supreme Court indicated it understood that Congress "not only overturned the specific holding in Gilbert, but also rejected the test of discrimination employed by the Court in that case."19 The Court cited House and Senate committee reports indicating that Congress believed the dissenting Justices had been correct in interpreting the prohibition on sex discrimination - as initially enacted - to proscribe pregnancy discrimination and that the PDA was intended to "reestablish" the proper interpretation of the law. ${ }^{20}$

Despite the clarity of the override, some courts have (mistakenly, I believe) continued to apply Gilbert as a shadow precedent in cases that address issues that are similar to pregnancy - in that they are unique to, or primarily experienced by, one sexbut arguably not directly addressed by the text of the PDA. For example, in cases challenging discrimination based on breastfeeding, some courts have held, citing Gilbert, that such policies do not constitute sex discrimination. ${ }^{21}$

The clear trend, however, is to repudiate this unduly narrow conception of Title VII. The leading case is EEOC v. Houston Funding II, Ltd..$^{22}$ In that case, the Fifth Circuit considered a claim brought by a woman who alleged she had been fired because she had indicated an interest in expressing breastmilk. Echoing the rationale of Satty, the court held that the employer's action violated "Title VII generally," because it imposed on women a "burden that male employees need not—indeed, could not—suffer." 23 The second, distinct, basis of the holding was that lactation is a "related medical condition of pregnancy" for purposes of the PDA. ${ }^{24}$ Since Houston Funding, other courts have similarly held discrimination based on breastfeeding violates Title VII, and that failure to

\footnotetext{
${ }^{19}$ Newport News Shipbuilding \& Dry Dock Co. v. Equal Emp. Opportunity Comm’n, 462 U.S. 669, 676 (1983); see also Young v. UPS, 575 U.S. 206, 226-27 (2015).

${ }^{20}$ Newport News, 462 U.S. at 678-79, 679 n.17; see also Widiss, Shadow Precedents, supra note 4, at 55253 (discussing this legislative history).

${ }^{21}$ See, e.g., Martinez v. N.B.C. Inc., 49 F. Supp. 2d 305, 309 (S.D.N.Y. 1999); Wallace v. Pyro Mining Co., 789 F. Supp. 867, 869 (W.D. Ky. 1990).

22717 F.3d 425 (5th Cir. 2013).

${ }^{23} \mathrm{Id}$. at 428 .

${ }^{24} I d$.
} 
accommodate lactation, to the extent that the employer accommodates other needs that cause similar limitations, can likewise violate the statute. ${ }^{25}$

"Related statute" questions have also arisen in this context. Courts have reached mixed results when interpreting state statutes that prohibit "sex" discrimination without explicitly mentioning pregnancy, with some reasoning that the absence of language equivalent to the PDA dooms the claim. ${ }^{26}$ One of the fullest discussions is a Sixth Circuit case interpreting Ohio's public accommodation law. ${ }^{27}$ Noting that Ohio had amended its employment discrimination law to incorporate language akin to the PDA, the court held that its failure to make similar changes in the public accommodation provisions meant lactation discrimination was outside the scope of the law. Many of these decisions predate the Supreme Court's causation decisions; the Court's reasoning in that context increases the likelihood that courts could deem a legislature's failure to amend a statute to be significant. ${ }^{28}$ However, it is important to note that other courts have (properly, I believe) held pregnancy discrimination to be within the ambit of a general prohibition on "sex" discrimination, even if the statute does not contain any language specifically referencing pregnancy, reasoning that the statutes can be interpreted differently from how Title VII was interpreted in Gilbert. ${ }^{29}$ Analogous arguments can be made in the context of menstruation discrimination, as developed in the next part.

\section{Menstruation Discrimination Is Sex Discrimination}

Cases challenging menstruation discrimination are a new chapter in this story, and the handful of published decisions suggest that courts will grapple with interpretive questions along both vectors: whether such discrimination violates Title VII itself, and whether it applies to other statutes that address sex discrimination.

Coleman v. Bobby Dodd Institute, Inc. was brought by an employee who was fired because heavy bleeding associated with pre-menopausal menstruation soiled company

\footnotetext{
${ }^{25}$ See, e.g., Hicks v. Tuscaloosa, 870 F.3d 1253 (11th Cir. 2017); Allen-Brown v. D.C., 174 F. Supp. 3d 463 (D.D.C. 2016).

${ }^{26}$ See, e.g., Delva v. Continental Grp., Inc. 96 So.3d 956 (Fla. App. 2012).

${ }^{27}$ Derungs v. Wal-Mart Stores, Inc. 374 F.3d 428 (6th Cir. 2004).

${ }^{28}$ See cases cited supra note 8.

${ }^{29}$ See, e.g., Mass. Elec. Co. v. Mass. Comm'n Against Discrimination, 375 N.E.2d 1192 (Mass. 1978); Badih v. Myerers, 43 Cal. Rptr. 2d 229 (Cal. App. 1995).
} 
property. The district court reviewed the history discussed above and concluded that, based on Congress's repudiation of Gilbert, a "non-frivolous argument" can be made that it's "unlawful for an employer to treat a uniquely feminine condition" less favorably than similar conditions affecting both sexes. ${ }^{30}$ Another recent district court case expressed support for this analysis. ${ }^{31}$ Although the courts' suggestion that a plaintiff would need to identify a male employee who was treated differently is unwarranted ${ }^{32}$ the recognition that menstruation discrimination could constitute sex discrimination is a promising development.

That said, in advancing such claims, advocates and theorists should seek to establish that menstruation discrimination is itself discrimination on the basis of "sex," in addition to any claim premised on the "related medical conditions" language in the PDA or other federal or state statutes with comparable language. ${ }^{33}$ (This same approach should be used to address discrimination on the basis of menopause, to the extent that it is considered distinct from discrimination on the basis of menstruation.) This may have practical value under Title VII itself. Although some courts have suggested menstruation fits within the

\footnotetext{
${ }^{30}$ No. 4:17-CV-29, 2017 WL 2486080, at *2 (M.D. Ga. June 8, 2017).

${ }^{31}$ Betancourt v. Margaritaville Hollywood, Beach Resort, L.P., No. 18-cv-62538, 2019 WL 2119611, at*2-3 (S.D. Fla. Mar. 29, 2019).
}

${ }^{32}$ Although it is common for courts to suggest a plaintiff must identify comparators outside the plaintiff's "protected class," Title VII's statutory language does not include any such requirement. See Suzanne B. Goldberg, Discrimination by Comparison, 120 YALE L.J. 728, 744 (2011). It is particularly inappropriate to require a comparator where the discriminatory bias expressed reflects sex-based stereotypes associated with menstruation, such as that menstruating persons are unclean and should not interact with others. $C f$.

Chadwick v. Wellpoint, Inc, 561 F.3d 38, 44-46 (1st Cir. 2009) (finding comparators are not necessary where adverse action was based on sex-based stereotypes assuming women would prioritizing caregiving over paid work).

${ }^{33}$ Title VII, as amended by the PDA, can require employers to accommodate pregnancy, childbirth, and related medical conditions, if they accommodate other conditions that cause similar limitations. However, it does not provide an absolute right to accommodation. As of August 2021, thirty states have enacted legislation that specifically requires accommodations for pregnancy, and most of these laws incorporate the "pregnancy, childbirth, or related medical conditions" language. See A Better Balance, State Pregnant Workers Fairness Laws (Aug. 12, 2021), https://www.abetterbalance.org/resources/pregnant-worker-fairnesslegislative-successes/ [https://perma.cc/QX4G-5F4H] (identifying states with relevant laws). In May 2021, the U.S. House passed a comparable bill. See H.R. 1065, Pregnant Workers Fairness Act, 117th Cong. (2021). Under these state laws, and the federal law if enacted, it might be in employees' interest to allege menstruation fits within the "related medical condition" language if they needed any kind of workplace accommodation connected to menstruation. 
"related medical condition" language, ${ }^{34}$ others have held it does not. ${ }^{35}$ The more subtle danger in relying exclusively on this language is that it is less likely to translate to the interpretation of other statutes. This may be a particular risk under Title IX, the federal statute that prohibits discrimination on the basis of "sex" in most educational programs. ${ }^{36}$ Title IX's regulations indicate that excluding students from educational activities based on "pregnancy" or "childbirth" violates the statute, but the regulations do not include the "related medical condition" language found in the PDA. ${ }^{37}$ This difference could permit an argument that while pregnancy discrimination is precluded by Title IX, menstruation discrimination is beyond the ambit of the statute.

Theorists and advocates addressing both employment-related and non-employmentrelated claims should therefore consistently argue that menstruation discrimination is sex discrimination, full-stop. As noted above, prior to Gilbert, the circuit courts and the EEOC unanimously stated that pregnancy discrimination was sex discrimination. ${ }^{38}$ The PDA simply clarified and restored that interpretation. Similarly, menstruation discrimination should be recognized as sex discrimination, whether or not statutes were amended with language similar to the PDA. Indeed, an early decision reaching this conclusion predates the PDA entirely. In Harper v. Thiokol Chemical Corp., the Fifth Circuit considered the legality of a policy that required employees who had been on maternity leave to have sustained a normal menstrual cycle before returning to work. ${ }^{39}$ Although the decision is from 1980, it was decided pursuant to the pre-PDA law, as the

\footnotetext{
${ }^{34}$ See Equal Emp. Opportunity Comm'n v. Houston Funding II, Ltd., 717 F.3d 425, 429-30 (5th Cir. 2013) ("[A]s both menstruation and lactation are aspects of female physiology that are affected by pregnancy, each seems readily to fit into a reasonable definition of 'pregnancy, childbirth, or related medical conditions."')

${ }^{35}$ See Jirak v. Fed. Ex. Corp., 805 F. Supp. 193 (S.D.N.Y. 1992) (holding PDA inapplicable in claim alleging termination for absences related to menstrual cramps on the ground "menstrual cramps are not a medical condition related to pregnancy or childbirth").

3620 U.S.C. $\S 1681$.

${ }^{37}$ See 34 CFR $\S 106.40$ (b) (precluding discrimination or exclusion of students from education programs or activities based on "pregnancy, childbirth, false pregnancy, termination of pregnancy or recovery therefrom").

${ }^{38}$ See supra text accompanying note 12.

${ }^{39} 619$ F.2d 489 (5th Cir. 1980).
} 
facts occurred in the early $1970 \mathrm{~s} .{ }^{40}$ Building on the Satty holding, the court concluded the policy "deprive[d] female employees of employment opportunities and imposes on them a burden which male employees need not suffer" and was therefore illegal since it was not a business necessity. ${ }^{41}$ Advocates may point to Harper, as well Congress's endorsement of the dissenters' reasoning in Gilbert, to support claims that discrimination on the basis of menstruation is properly recognized as discrimination on the basis of sex, under both Title VII and other statutes that prohibit sex discrimination.

\section{CONCLUSION}

There have been relatively few cases challenging menstruation discrimination, but the growing menstrual justice movement suggests that they are likely to become more prevalent. These cases build on earlier litigation and legislation addressing pregnancy discrimination. When Congress repudiated the Supreme Court's cramped understanding of sex discrimination by enacting the PDA, it rejected not only the specific holding of Gilbert but also its reasoning. Menstruation, like pregnancy, is a condition linked to female biology and associated with stereotypical assumptions about women's proper role in society. Discrimination based on menstruation should be recognized as sex discrimination, not only under Title VII as amended by the PDA, but also under other federal and state laws, regulations, and constitutional provisions that prohibit discrimination on the basis of sex.

\footnotetext{
${ }^{40}$ Overrides are presumptively prospective, whereas judicial interpretations are presumptively retroactive. See Widiss, Shadow Precedents, supra note 4 at 534-36. Accordingly, the court properly followed Satty but did not apply the PDA.

${ }^{41} 619$ F.2d at 492. In accordance with Gilbert, the court considered the policy to be facially neutral, but unlawful because it caused a disparate impact without sufficient business justification. However, in EEOC v. Houston Funding, the court referenced Thiokol to support its holding that lactation discrimination constituted disparate treatment on the basis of sex, 717 F.3d 425, 427 (5th Cir. 2013), a conclusion bolstered by Congress's repudiation of Gilbert.
} 